\title{
Investigating Prospective Social Studies Teachers' Perceptions of European Union through Metaphor Analysis
}

\author{
İsmail Hakan Akgün \\ Correspondence: İsmail Hakan Akgün, Assist. Prof. Dr., Adıyaman University, Education Faculty, Department of Social \\ Science and Turkish Education, Adiyaman, Turkey. \\ Received: December 26, 2016 \\ Accepted: January 10, $2017 \quad$ Online Published: January 16, 2017 \\ doi:10.11114/jets.v5i3.2161 \\ URL: http://dx.doi.org/10.11114/jets.v5i3.2161
}

\begin{abstract}
The purpose of this study is to investigate metaphors developed by social studies teacher candidates about the European Union. 185 second, third and fourth year social studies teacher candidates participated in the study. This study was designed as a phenomenological study and matephor analysis was conducted. At the end of the study, the students developed 168 metaphors about the European Union. The metaphors developed by the students were grouped into 4 categories after coding and extracting phases. The categories were (1) a religious community, (2) a seemingly powerful but decadent formation, (3) a powerful formation and (4) does anything for its own interest. It was determined in the study that the students perceived the EU mostly as a powerful formation (36.14\%), followed by a religious community $(34.33 \%)$, does anything for its own interest $(20.48 \%)$ and a seemingly powerful but decadent formation (8.43\%).
\end{abstract}

Keywords: social studies, the European Union, metaphor

\section{Introduction}

Many states, especially after the destruction created by World War II, started to recover quickly and initiated a rapid improvement process. Those modern countries that have made progress in science and technology showed fast advancements. Many contemporary countries have chosen to join international organizations such as North Atlantic Treaty Organization (NATO), Organization for Economic Cooperation and Development (OECD) and the European Union (EU) for military, political, economical and strategical reasons.

Since its establishment, Republic of Turkey has always followed international developments and joined international organizations such as OECD and NATO towards the goal of raising the level of contemporary civilizations. Shortly after the European Economic Community (EEC) was founded in 1958, which was considered to be the biggest peace project in the history, Turkey did not remain indifferent and made an application for full membership in July, 1959. Following this application, the EEC notified that Turkey's level of development was insufficient for full membership and suggested a partnership agreement that would be valid until Turkey's full membership requirements were fulfilled. Accepted by Turkey and signed on September 12, 1963, Ankara Agreement envisaged a three-stage process, including preparation, transition and final stages for Turkey's integration to the EEC. The preparation period that was stipulated in the agreement ended when Additional Protocol was come into force in 1973 and thus the transition period has started. The slowly progressing transition period with the effects of economic difficulties in 1970s and 1980 military coup finally came to an end with Turkey's entry to the Customs Union in 1996. In Helsinki Summit, dated December 10-11, 1999, Turkey's candidacy for full membership has been approved. Thus, a new era has started between Turkey-EU relations which have a long history. The Brussels Summit held on December, 17, 2004 was an important milestone in Turkey-EU relations. In this summit, it was stated that Turkey has adequately met political criteria and it was recommended to start negotiations for full membership with Turkey on October 3, 2005. The parties have initiated negotiations on the suggested date and the acquis work still continues (Republic of Turkey, Ministry for European Union Affairs, http://www.ab.gov.tr/index.php?p=4).

In the EU accession process, Turkey has made many economic, political, social and cultural regulations. For example, in 2002 the death penalty was removed from the Turkish Criminal Code, languages other than Turkish have been allowed in media and education, freedom of expression has been expanded, the punishment of serious crimes such as torture have been increased. These multifaceted regulations that Turkey made towards its EU membership have eventually affected the Turkish society. However, because there is insufficient debriefing provided about the EU and 
because K-12 courses do not have enough content about the EU, for most of the society what people know about the EU does not go beyond what they hear from the media. As for the university level, some programs offer elective courses related to the EU. In this context, Adiyaman University, Faculty of Education, Social Studies Education program offers Europe-Turkey Relations course as two sections in 2nd and 3rd year of the program for 2 hours per week. The content of these courses included, but not limited to, the history of European integration, EU-Turkey relations, Turkey's EU structure and Turkey's regulations on its way to EU.

In this respect, this study examined metaphors for the EU developed by Social Studies Education program students at Adiyaman University, Faculty of Education.

Metaphor is defined as shaping words and expressing by analogy (Riccoeur, 2003). A metaphor is used to describe a concept with expressions from a different conceptual area (Kovacses, 1993). Metaphor is a tool for uncovering thoughts in our mind and it gives the opportunity to understand ourselves and the outside world in a way that we are not familiar with (Lakoff and Turner, 1989). It is an important method to determine the nature of the key concepts and different perspectives (Singh, 2010). Metaphor is considered as a tool that people use when they try to explain life, environment, how they see events and objects by using different analogies (Cerit, 2008). Metaphorical thinking and learning along with effective and scientifically proven teaching methods aims at developing students' creative and critical thinking skills. Metaphor has gained attention as a powerful mental mapping and modeling mechanism towards individuals' effort to understand and structure their world (Arslan ve Bayrakçı, 2006).

Metaphors are only thought to be used to embellish one's conversation in everyday life, but the metaphor means more than that for human life. For educators, metaphors help to make comparisons, to detect similarities and to explain something by replacing it with something else (Saban, 2004).

Recently, especially in Turkey, there has been a growing interest for metaphor studies from different disciplines (Ortony, 2002). Indeed, Saban (2004), Saban (2008), Cerit (2008), Saban (2009), Geçit and Gençer (2011) have used metaphors in their studies. However, there is little or no metaphor studies in Turkey about the EU. In this respect, the main purpose of this study, which also aims to fill abovementioned gap in the literature, is to reveal social studies teacher candidates' mental images about the EU. While Turkey is moving towards full membership for the EU, investigating university students' thoughts about the EU through metaphors can be considered as an important source of information.

\subsection{Purpose of the Study}

The purpose of this study is to examine metaphors developed by teacher candidates for the EU. Relevant to this purpose, current study investigated the metaphors of $2^{\text {nd }}, 3^{\text {rd }}$ and $4^{\text {th }}$ year social studies teacher candidates enrolled in Adiyaman University, Faculty of Education about the EU and sought the question of what causes the development of these metaphors.

\section{Method}

In this section, information is given about research design, study group, data collection and data analysis.

\subsection{Research Design}

This study was designed as a phenomenological study. Phenomenology focuses on the facts that we are aware but we do not have a detailed understanding about. For investigating the facts that are not completely foreign to us, but we cannot fully comprehend, phenomenology is an appropriate method (Yılmaz \& Şimsek, 2006).

\subsection{Study Group}

The study was conducted with 185 second, third and fourth year students enrolled in Social Studies Education program at Adiyaman University, Faculty of Education in 2014-2015 academic year. Frequency and percentage distributions by gender and grade level of the students who participated in the study are given in Table 1.

Table 1. Gender and Grade Level of Students Participated in the Study

\begin{tabular}{llrl}
\hline & & Frequency $(f)$ & Per cent $(\%)$ \\
\hline \multirow{2}{*}{ Gender } & Female & 66 & 35.7 \\
\cline { 2 - 4 } & Male & 119 & 64.3 \\
\hline \multirow{3}{*}{ Grade } & 2nd year & 64 & 34.6 \\
\cline { 2 - 4 } & 3rd year & 46 & 24.8 \\
\cline { 2 - 4 } & 4th year & 75 & 40.5 \\
\hline
\end{tabular}

As shown in Table 1, 66 (35.7\%) female and $119(64.3 \%)$ male students participated in the study. The participants consist of $64(34.6 \%)$ second year, $46(24.8 \%)$ third year and $75(40.5 \%)$ fourth year students.

\subsection{Data Collection}

In order to determine the metaphors participating students have about the EU, students were asked to complete the 
sentence "EU is like because " by using only one metaphor. Data were collected during a 40-minute course period.

\subsection{Data Analysis}

In order to determine a current situation, this study utilized metaphor analysis. Obtained data as gender, grade level, metaphors and reasons were entered to a table created in a Microsoft Excel document and the metaphors were listed in alphabetical order. Then, by examining each metaphor individually, the frequency (f) and percentage (\%) calculations were completed. After the data entry process, 9 forms were excluded from the study due to missing information or failure to establish a logical link between the metaphor and the reason provided. Eventually, 168 valid metaphors were included in the analysis. Among those, main categories were created by grouping similar metaphors. "Because ......" sentences were considered decisive for the classification of the metaphors. Accordingly, metaphor phrases that best represent the groups were listed under related categories with their reasons. Consequently, metaphors developed by the students were grouped under 4 main categories and were described in detail. In a literature review, it has been found that Ocak and Gunduz (2006), Saban (2008, 2009), Guven and Guven (2009), and Ozer and Turel (2015) followed a similar data analysis process in their metaphor studies.

\subsection{Validity and Reliability}

In qualitative studies, reporting the data in detail and explaining how the researchers reached their conclusions are considered important in terms of validity of the study (Yıldırım ve Şimsek, 2006). In this context, conceptual categories have been created in a detailed manner by identifying, extracting and coding the metaphors, and the students' opinions that were considered as important related to the categories were included.

In order to ensure the reliability of the study, after the metaphors were categorized, an expert has been consulted to match the categories and the metaphors. The consensus and disagreement between the expert and the researcher was calculated using Miles and Huberman (1994; Akt, Saban, 2008) by the "Reliability $=$ (Consensus / [consensus + disagreement]) * 100 " formula as $92 \%$. This value indicates that the coding has a quite high reliability.

\section{Findings}

Metaphors developed for the European Union were grouped under four main categories after being subjected to coding and extracting phases. The categories were listed as (1) a religious community, (2) a seemingly powerful but decadent formation, (3) a powerful formation and (4) does anything for its own interest. While creating the categories, the reasons for choosing the metaphors were taken into account. The explanations students made by completing the "Because ......" sentences were considered decisive for the classification of the metaphors. Therefore it some metaphors were included in multiple categories based on the meaning attributed to them.

When we examine the categories, a powerful formation had the largest portion of the metaphors with $36.74 \%$. The categories containing the metaphors created for the EU are given in Table 2.

Table 2. Conceptual Categories Related to the EU

\begin{tabular}{lll}
\hline Category & f & $\%$ \\
\hline A religious community & 57 & 34.33 \\
\hline $\begin{array}{l}\text { A seemingly powerful but decadent } \\
\text { formation }\end{array}$ & 14 & 8.43 \\
\hline A powerful formation & 61 & 36.74 \\
\hline Does anything for its own interest & 34 & 20.48 \\
\hline Total & 166 & 100 \\
\hline
\end{tabular}

The findings obtained from the analysis of the metaphors developed by social studies teacher candidates for the European Union are given below.

Category 1: A religious community: Students in this category stated that generally the European Union is a community that was established on religious foundations and that this is the reason why Turkey has not been accepted to the European Union. Students developed 57 metaphors related to the category of a religious community. Some statements in this category are as follows:

O32: "The European Union is a kind of holy crusade union, because the member states are Christians. Turkey is a Muslim country, so they will not accept Turkey's membership."

O61: "The European Union is like a Christian unity, because none of the members are Muslims and they don't accept Turkey to the Union with various excuses."

O189: "The European Union is like a house with closed doors, because we are an Islamic country, so they won't let us to the European Union." 
O76: "It is like a beautiful and rich girl, because when Turkey expresses its desire, it produces continuous excuses, but it actually does not want to take Turkey for religious reasons."

Data concerning metaphors that qualify the EU as a religious community are presented in Table 3.

Table 3. Metaphors That Qualifies the EU as "A Religious Community"

\begin{tabular}{|c|c|c|c|c|c|c|}
\hline Metaphor & Female & & Male & & Total & \\
\hline & $\mathrm{f}$ & $\%$ & $\mathrm{f}$ & $\%$ & $\mathrm{f}$ & $\%$ \\
\hline Turtle & 1 & 1.75 & 0 & 0 & 1 & 1,75 \\
\hline Useless friend & 1 & 1.75 & 0 & 0 & 1 & 1,75 \\
\hline Nation & 0 & 0 & 1 & 1.75 & 1 & 1,75 \\
\hline $\begin{array}{l}\text { Teacher obsessed with } \\
\text { students }\end{array}$ & 1 & 1.75 & 0 & 0 & 1 & 1,75 \\
\hline Offside goal & 1 & 1.75 & 0 & 0 & 1 & 1,75 \\
\hline Cat & 1 & 1.75 & 0 & 0 & 1 & 1,75 \\
\hline Beautiful and rich girl & 0 & 0 & 2 & 3.50 & 2 & 3,50 \\
\hline Christian unity & 1 & 1.75 & 6 & 10.5 & 7 & 12.25 \\
\hline Coy lover & 2 & 3.50 & 0 & 0 & 2 & 3.50 \\
\hline $\begin{array}{l}\text { National Ministry } \\
\text { Education }\end{array}$ & 1 & 1.75 & 0 & 0 & 1 & 1.75 \\
\hline Swing & 1 & 1.75 & 0 & 0 & 1 & 1.75 \\
\hline Utopia & 0 & 0 & 2 & 3.50 & 2 & 3.50 \\
\hline Sports writer & 0 & 0 & 1 & 1.75 & 1 & 1.75 \\
\hline Ku Klux Klan organization & 0 & 0 & 1 & 1.75 & 1 & 1.75 \\
\hline Apple tree & 0 & 0 & 1 & 1.75 & 1 & 1.75 \\
\hline Church & 0 & 0 & 2 & 3.50 & 2 & 3.50 \\
\hline Opposite ended magnet & 2 & 3.50 & 2 & 3.50 & 4 & 7 \\
\hline Stepmother/stepfather & 2 & 3.50 & 2 & 3.50 & 4 & 7 \\
\hline Airplane & 0 & 0 & 1 & 1.75 & 1 & 1.75 \\
\hline Brain & 0 & 0 & 1 & 1.75 & 1 & 1.75 \\
\hline Father detaining his child & 0 & 0 & 2 & 3.50 & 2 & 3.50 \\
\hline Landlord & 1 & 1.75 & 0 & 0 & 1 & 1.75 \\
\hline Salt-sugar & 0 & 0 & 1 & 1.75 & 1 & 1.75 \\
\hline Mother of an arrogant girl & 1 & 1.75 & 0 & 0 & 1 & 1.75 \\
\hline Crusader army & 1 & 1.75 & 1 & 1.75 & 2 & 3.50 \\
\hline Broken watch & 0 & 0 & 1 & 1.75 & 1 & 1.75 \\
\hline Goat & 1 & 1.75 & 0 & 0 & 1 & 1.75 \\
\hline Swamp & 1 & 1.75 & 0 & 0 & 1 & 1.75 \\
\hline Pig & 1 & 1.75 & 0 & 0 & 1 & 1.75 \\
\hline Octopus & 1 & 1.75 & 0 & 0 & 1 & 1.75 \\
\hline Home with closed doors & 0 & 0 & 1 & 1.75 & 1 & 1.75 \\
\hline Coach & 0 & 0 & 1 & 1.75 & 1 & 1.75 \\
\hline Soap opera & 0 & 0 & 1 & 1.75 & 1 & 1.75 \\
\hline Cancer patient & 0 & 0 & 1 & 1.75 & 1 & 1.75 \\
\hline Platonic love & 0 & 0 & 2 & 3.50 & 2 & 3.50 \\
\hline Incorporated company & 0 & 0 & 1 & 1.75 & 1 & 1.75 \\
\hline Flock & 0 & 0 & 1 & 1.75 & 1 & 1.75 \\
\hline Dump & 1 & 1.75 & 0 & 0 & 1 & 1.75 \\
\hline Total: & & & & & 57 & 100 \\
\hline
\end{tabular}

Though it is not obvious that students qualified the European Union as a religious community in their metaphors, in "because ......" sentences students underlined that the EU is a religious community.

Category 2: A seemingly powerful but decadent formation: Students in this category stated that the European Union, especially in economic terms, is about to spread and come to an end. Under this category, a total of 14 metaphors were developed and some of the statements are as follows:

O94: "The European Union is like sugar. It is sweet, but it melts like sugar and the taste disappears. Even if it seems economically strong, it is doomed to collapse."

O151: "The European Union is like a ballpoint pen. Turkey wants to join the European Union, but the European Union is on the verge of economic collapse. So, the ink of the pen is about to run out."

O40: "The European Union is like a maze, because its course is complicated, its way is sinuous and its end is unclear."

Data related to the metaphors that characterize the European Union as a seemingly powerful but decadent formation are given in Table 4. 
Table 4. Metaphors That Qualifies the EU as "A Seemingly Powerful but Decadent Formation"

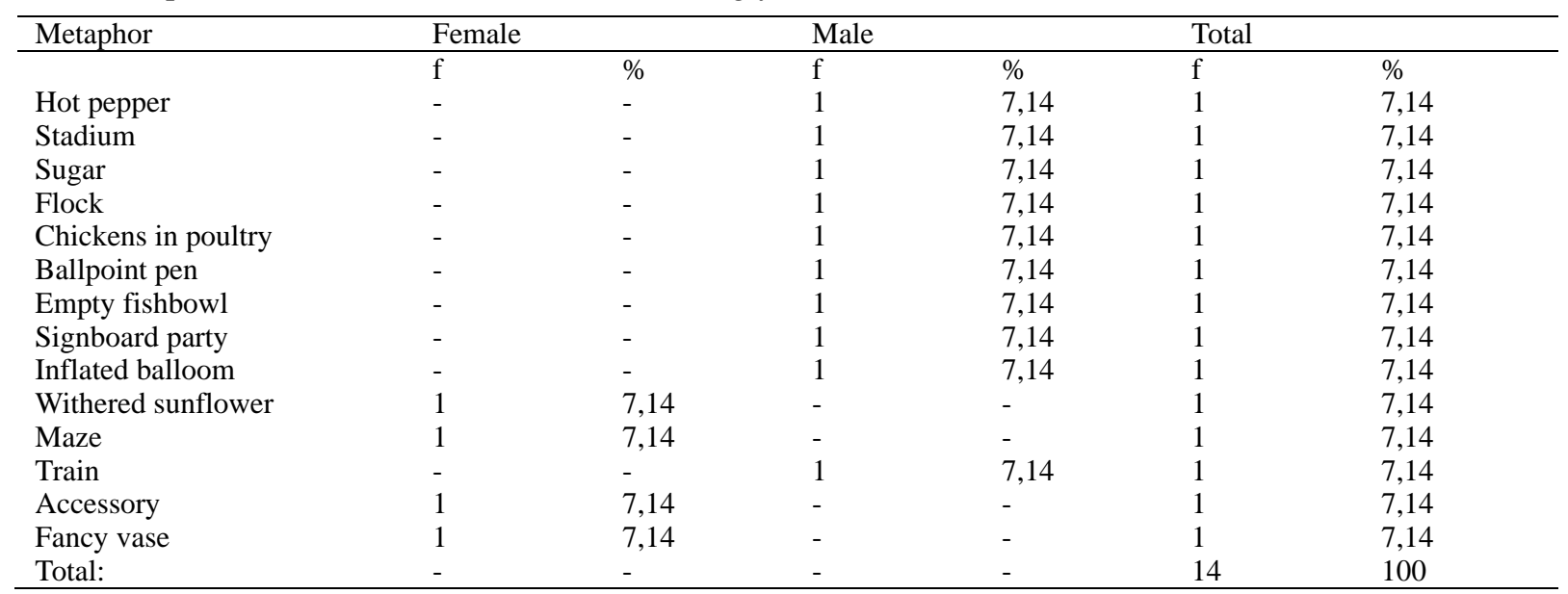

Category 3: A powerful formation: In this category, students describe the European Union as a strong structure protects and always supports its member states. This category, in which the most metaphors were developed, includes a total of 61 metaphors. Some of the metaphors are as follows:

O77: "The European Union is like a puzzle, because different and developed countries have created a stronger structure by coming together."

O136: "The European Union is like prom night in the palace. Like wealthy people may come to a Prom night, the European Union gathers economically and democratically developed countries."

O152: "The European Union is like a football team, because the team members are useless alone; they are much stronger only as a team."

O31: "The European Union is like an umbrella, because an umbrella retains what is under, similarly, the European Union protects its member states in economic and other areas."

Data related to the metaphors that characterize the European Union as a powerful formation are given in Table 5. 
Table 5. Metaphors Related to the Category of "A Powerful Formation"

\begin{tabular}{|c|c|c|c|c|c|c|}
\hline Metaphor & Female & & Male & & Total & \\
\hline & $\mathrm{f}$ & $\%$ & $\mathrm{f}$ & $\%$ & f & $\%$ \\
\hline Unique tree & 3 & 4.98 & 2 & 3.33 & 5 & 8.3 \\
\hline Filter & 1 & 1.66 & - & - & 1 & 1.66 \\
\hline Huge state & 3 & 4.98 & 6 & 9.96 & 9 & 14.94 \\
\hline Human & 1 & 1.66 & - & - & 1 & 1.66 \\
\hline Entrance door & 1 & 1.66 & - & - & 1 & 1.66 \\
\hline Puzzle & - & - & 2 & 3.33 & 2 & 3.33 \\
\hline University & - & - & 1 & 1.66 & 1 & 1.66 \\
\hline Machine & - & - & 1 & 1.66 & 1 & 1.66 \\
\hline Vegetable market & - & - & 1 & 1.66 & 1 & 1.66 \\
\hline Head of the family & - & - & 1 & 1.66 & 1 & 1.66 \\
\hline Capital & - & - & 1 & 1.66 & 1 & 1.66 \\
\hline Pomegranate & - & - & 1 & 1.66 & 1 & 1.66 \\
\hline Train & - & - & 1 & 1.66 & 1 & 1.66 \\
\hline Ocean & - & - & 1 & 1.66 & 1 & 1.66 \\
\hline Billard balls & - & - & 1 & 1.66 & 1 & 1.66 \\
\hline Vine & - & - & 1 & 1.66 & 1 & 1.66 \\
\hline Roof & 1 & 1.66 & - & - & 1 & 1.66 \\
\hline Shipmaster & 1 & 1.66 & - & - & 1 & 1.66 \\
\hline Digestive system & & & 1 & 1.66 & 1 & 1.66 \\
\hline Cement & 1 & 1.66 & - & - & 1 & 1.66 \\
\hline Music band & - & - & 1 & 1.66 & 1 & 1.66 \\
\hline TV remote & 1 & 1.66 & - & - & 1 & 1.66 \\
\hline Telephone & - & - & 1 & 1.66 & 1 & 1.66 \\
\hline Super league & - & - & 1 & 1.66 & 1 & 1.66 \\
\hline Protective mechanism & - & - & 1 & 1.66 & 1 & 1.66 \\
\hline Museum & 1 & 1.66 & - & - & 1 & 1.66 \\
\hline Prom night & - & - & 1 & 1.66 & 1 & 1.66 \\
\hline Family & 1 & 1.66 & 1 & 1.66 & 2 & 3.33 \\
\hline King of the jungle (lion) & 1 & 1.66 & - & - & 1 & 1.66 \\
\hline Beaten person & - & - & 1 & 1.66 & 1 & 1.66 \\
\hline Football team & 1 & 1.66 & - & - & 1 & 1.66 \\
\hline Sea & 1 & 1.66 & - & - & 1 & 1.66 \\
\hline Community of relatives & - & - & 1 & 1.66 & 1 & 1.66 \\
\hline Tasty meal & - & - & 1 & 1.66 & 1 & 1.66 \\
\hline Organism & - & - & 2 & 3.33 & 2 & 3.33 \\
\hline Father & - & - & 2 & 3.33 & 2 & 3.33 \\
\hline Bridge & - & - & 2 & 3.33 & 2 & 3.33 \\
\hline Shepherd & - & - & 1 & 1.66 & 1 & 1.66 \\
\hline Fingers of a hand & - & - & 1 & 1.66 & 1 & 1.66 \\
\hline Heart & 1 & 1.66 & - & - & 1 & 1.66 \\
\hline Umbrella & - & - & 1 & 1.66 & 1 & 1.66 \\
\hline Top of the mountain & - & - & 1 & 1.66 & 1 & 1.66 \\
\hline Tourist & - & - & 1 & 1.66 & 1 & 1.66 \\
\hline Cosmopolitan magazine & 1 & 1.66 & - & - & 1 & 1.66 \\
\hline Total: & & & & & 61 & 100 \\
\hline
\end{tabular}

Category 4: Does anything for its own interest: In this category, students state that the European Union acts in line with its interests and doesn't care about others when their interests conflict. A total of 34 metaphors have been developed in this category and some of these are as follows:

O4: "The European Union is like a vampire, because it exploits others to survive."

O45: "The European Union is like a mixer, because it wants to mix the relations of other states in order to protect its interests."

O15: "The European Union is like a chameleon, because it changes color in line with its own interests."

Data related to the metaphors that characterize the European Union as it does anything for its own interest are given in Table 6. 
Table 6. Metaphors Developed within the Category of "Does Anything for its Own Interest"

\begin{tabular}{|c|c|c|c|c|c|c|}
\hline Metaphor & Female & & Male & & Total & \\
\hline & f & $\%$ & $\mathrm{~F}$ & $\%$ & $\mathrm{f}$ & $\%$ \\
\hline Fox & 1 & 2.94 & 2 & 5.88 & 3 & 8.82 \\
\hline Vampire & - & - & 1 & 2.94 & 1 & 2.94 \\
\hline Scorpion & - & - & 1 & 2.94 & 1 & 2.94 \\
\hline Snake & 1 & 2.94 & - & - & 1 & 2.94 \\
\hline Auction hall & - & - & 1 & 2.94 & 1 & 2.94 \\
\hline Artisan & - & - & 1 & 2.94 & 1 & 2.94 \\
\hline Chameleon & 2 & 5.88 & 3 & 8.82 & 5 & 14.7 \\
\hline Characterless person & - & - & 1 & 2.94 & 1 & 2.94 \\
\hline Soccer bench & - & - & 1 & 2.94 & 1 & 2.94 \\
\hline $\begin{array}{ll}\text { Institution } & \text { employin } \\
\text { unnecessary staff }\end{array}$ & - & - & 1 & 2.94 & 1 & 2.94 \\
\hline Turtle & - & - & 1 & 2.94 & 1 & 2.94 \\
\hline Cruel Nimrod & 1 & 2.94 & - & - & 1 & 2.94 \\
\hline Sledgehammer & 1 & 2.94 & - & - & 1 & 2.94 \\
\hline Mannequin & - & - & 1 & 2.94 & 1 & 2.94 \\
\hline Puppet & - & - & 1 & 2.94 & 1 & 2.94 \\
\hline Cruel boss & 1 & 2.94 & - & - & 1 & 2.94 \\
\hline Chaos & 1 & 2.94 & - & - & 1 & 2.94 \\
\hline Tidal event & - & - & 1 & 2.94 & 1 & 2.94 \\
\hline Mixer & 1 & 2.94 & - & - & 1 & 2.94 \\
\hline Manipulative friend & - & - & 1 & 2.94 & 1 & 2.94 \\
\hline Cat & - & - & 1 & 2.94 & 1 & 2.94 \\
\hline Human & - & - & 1 & 2.94 & 1 & 2.94 \\
\hline Half of an apple & 1 & 2.94 & - & - & 1 & 2.94 \\
\hline Pen & 1 & 2.94 & - & - & 1 & 2.94 \\
\hline Lion & - & - & 1 & 2.94 & 1 & 2.94 \\
\hline Violent husband & 1 & 2.94 & - & - & 1 & 2.94 \\
\hline Gypsy & - & - & 1 & 2.94 & 1 & 2.94 \\
\hline Tin & 1 & 2.94 & - & - & 1 & 2.94 \\
\hline Total: & & & & & 34 & 100 \\
\hline
\end{tabular}

\section{Discussion}

At the end of the study, it was observed that students developed maximum number of metaphors for the European Union in the category of "a powerful formation". Students in this category describe the European Union as a strong structure protects and always supports its member states. Under this category, the metaphor with the highest frequency (9 [14.94\%]) qualifies the EU as a huge state. A metaphor developed in this category are as follows: O31: "The European Union is like an umbrella, because an umbrella retains what is under, similarly, the European Union protects its member states in economic and other areas.".

In one of the findings of the study, students stated that the EU is a community that was established on entirely religious foundations and that this is the reason why Turkey has not been accepted to the European Union. Students developed 57 metaphors related to the category of $a$ "religious community". The largest number of metaphors developed by students in this category (7 [12.25\%]) is Christian Union. A metaphor developed in this category is as follows: O189: "The European Union is like a house with closed doors, because we are an Islamic country, so they won't let us to the European Union.". Along with its inclusion to the Candidate Countries Eurobarometer (Candidate Countries Eurobarometer-CCEB) in 2001, Turkey has been included in the Eurobarometer study held by the European Commission and the researchers had the opportunity to investigate Turkish public opinion with more detailed and advance techniques. Support for European Union membership is measured with data obtained from the question "membership is a good thing" which is regularly asked in the Eurobarometer. When we examine Turkish public's view of Turkey's EU membership and how it varies in time, it is observed that while public opinion has been positive since 2001, it tends to decrease over time (Senyuva, 2009).

In one of the research results, students state that the European Union acts in line with its interests and doesn't care about others when their interests conflict. In this category, students developed 34 metaphors and one of them is as follows: O4: "The European Union is like a vampire, because it exploits others to survive."

In another finding of the study, students stated that the European Union, especially in economic terms, is about to spread and come to an end. Under this category, a total of 14 metaphors were developed and one of the statements is as follows: O151: "The European Union is like a ballpoint pen. Turkey wants to join the European Union, but the European Union is on the verge of economic collapse. So, the ink of the pen is about to run out." 
Reviewing the literature, it can be observed that in the study of Akpinar (2006), 59.7\% of the students expressed the view that Turkey cannot be accepted to the European Union. Again, in the surveys conducted by International Strategic Research Organization (ISRO) (2006), the ratio of the participants who responded as no to the question "Does the EU act fair and friendly against Turkey?" was 55\% in 2004, 64\% in 2005 and $81 \%$ in 2006. Although, the support from Turkish society for the EU membership was around $75 \%$ at the beginning of 2000 s, this support was about $50 \%$ in ISRO's polls in 2006 and was decreased to $39.85 \%$ in a questionnaire conducted by Ercan (2012). These findings are in line with this study in which metaphors developed by teacher candidates for the European Union have been evaluated, because teacher candidates have generally developed negative metaphors for the EU.

\section{Result}

When the results of the study examined, it was determined that students perceived the EU mostly as a powerful formation (36.14\%). Then, students qualified the European Union as a religious community (34.33\%), does anything for its own interest (20.48\%) and a seemingly powerful but decadent formation $(8.43 \%)$.

\section{Suggestions}

Universities should offer courses related to Turkey's EU membership process, because it was observed in this study that lessons in the university curriculum about the European Union are not sufficient. People should be informed about the European Union and its member states, because it was found that there is a lack of research about this issue in Turkey and what people know about the EU is limited to what they hear from media. Furthermore, it was determined in this study that university students' mental images related to the European Union are mostly negative. This issue should also be investigated.

\section{References}

Akpınar, B. (2006). The European Union image of the Turkish primary school students in the process of integration to the European Union. Journal of Policy Analysis and Strategic Studies in Education, 1, 8-26.

$\begin{array}{lllll}\text { Avrobarometre (Candidate } & \text { Countries } & \text { Euro } & \text { Barometer-CCEB) } & \text { (2012). From }\end{array}$ $<$ http://ec.europa.eu/public_opinion/cf/showtable.cfm?keyID=5\&nationID=30,\&startdate=2004.10\&enddate=2012 $.11>$ (Retrieved January 04, 2016)

Ercan, M. (2012). Bilecik University Survey of the European Union the Turkish publish is how looking at the EU? Cumhuriyet University Journal of Social Sciences, 36(1), 199-220.

Geçit, Y., \& Gençer, K. (2011). Determining the geographical perception of the 1st. grade students in the department of primary education through metaphor (Example f Rize University). Marmara Geographical Review, 23, 1-19

Güven, B., \& Güven, S. (2009). Quantitative analysis relating to forming of metaphor which was made in social studies lesson by primary school students. Kastamonu Education Journal, 17(2), 503-512.

International Strategic Research Organisation (2006). Avrupa Birliği Algılama Anketi, From< http://www.usak.org.tr/dosyalar/usak-agilama-anketi-3.pdf> (Retrieved March10. 2011)

Kovecses, Z. (1993). Metaphor: A practical introduction. Oxford University Press [E-Book]. From<https://books.google.com.tr/books?hl=tr\&lr=\&id=zlsm5XpRGYMC\&oi=fnd\&pg=PR19\&dq=metaphor\&ot $\mathrm{s}=$ SwJookrYKX\&sig=juORUOGfORVAObraGJUbyWtAXPQ\&redir_esc $=\mathrm{y} \# \mathrm{v}=$ onepage $\& \mathrm{q}=$ metaphor $\& \mathrm{f}=\mathrm{false}>(\mathrm{R}$ etrieved November 24, 2015)

Lakoff, G., \& Turner, M. (2009). More than cool reason: A field guide to poetic metaphor. University of Chicago Press.

Ocak, G., \& Gündüz, M. (2006). The comparison of pre-service teachers' metaphors about the teacher-profession before and after the 'introduction to teacher-profession' course. Afyon Kocatepe University Journal of Social Sciences, 8(2), 293-310.

Ortony, A. (1993). Metaphor and thought. Cambridge University Press [E-Book]. Form $<$ https://books.google.com.tr/books?hl=tr\&lr=\&id=QiJRvuXA_VcC\&oi=fnd\&pg=PR11\&dq=metaphor\&ots=dafm ETElSG\&sig=4i0uYPauk9LqCS1D-HM-ndogRCk\&redir_esc=y\#v=onepage\&q=metaphor\&f=false> (Retrieved November 24, 2015)

Özer, S., \&Türel, Y. K. (2015). ICT Teacher Candidates’ Metaphoric Perceptions of E-Book and Interactive E-Book. Turkish Online Journal of Qualitative Inquiry, 6(2), 1-23. https://doi.org/10.17569/tojqi.33601

Republic of Turkey, Ministry for European Union Affair (2010). From <http://www.ab.gov.tr/index.php?p=4> (Retrieved January 04, 2016).

Ricoeur, P. (2003). The rule of metaphor: The creation of meaning in language. Psychology Press. 
Saban, A. (2004). Entry level prospective classroom teachers' metaphors about the concept of "teacher". Journal of Turkish Educational Sciences, 2(2), 131-155.

Saban, A. (2008). Primary school teachers' and their students' mental images about the concept of knowledge. Elementary Education Online, 7(2), 421-455.

Saban, A. (2009). Prospective teachers' mental images about the concept of student. Journal of Turkish Educational Sciences, 7(2), 281-326.

Şenyuva, Ö. (2009). Public opinion of turkey and European union 2001-2008: expectations, requests, and apprehensions. International Relations, 6(22), 97-123.

Singh, K. (2010). Metaphor as a tool in educational leadership classrooms. Management In Education, 24(3), 127-131. https://doi.org/10.1177/0892020608090411

Yıldırım, A., \& Şimşek, H. (2006). Qualitative research techniques in social sciences. Ankara, Turkey: Seçkin Yayıncilık.

\section{Copyrights}

Copyright for this article is retained by the author(s), with first publication rights granted to the journal.

This is an open-access article distributed under the terms and conditions of the Creative Commons Attribution license which permits unrestricted use, distribution, and reproduction in any medium, provided the original work is properly cited. 